\title{
Effect of calcium oxalate on the photocatalytic degradation of Orange II on $\mathrm{ZnO}$ surface
}

\author{
S. Bassaid - B. Ziane - M. Badaoui • \\ M. Chaib - D. Robert
}

Received: 31 January 2012/ Accepted: 24 March 2012/Published online: 25 April 2012

(C) The Author(s) 2012. This article is published with open access at Springerlink.com

\begin{abstract}
The photocatalytic degradation of aqueous solution of Orange II, has been investigated in the presence of $\mathrm{ZnO}$ catalyst with calcium oxalate as sacrificial agent. This study demonstrated that the performance of $\mathrm{ZnO}$ photocatalyst can be improved by addition of calcium oxalate. Results show that adsorption is an important parameter controlling the degradation phenomena. Indeed, the added oxalate causes a drop in the $\mathrm{pH}$ medium, what causes a better adsorption of Orange II on the $\mathrm{ZnO}$ surface. The effect of calcium oxalate is to increase the concentration of superoxides $\left(\mathrm{O}_{2}^{-}\right)$and hydroperoxides $\left(\mathrm{HO}_{2} \cdot\right)$ radicals, which are key intermediaries in the mechanism of photodegradation because of their powerful force of oxidation.
\end{abstract}

Keywords $\mathrm{ZnO}$ - Photocatalysis - Organic pollutants . Orange II · Photocatalytic degradation · Sacrificial agent

\section{Introduction}

Heterogeneous photocatalysis is an efficient technique to destroy organic pollutants in water (Rajeshwara et al. 2008; Garcia et al. 2009). The basic process of photocatalysis

S. Bassaid · B. Ziane - M. Badaoui · M. Chaib Laboratoire de Chimie et Environnement, Université Ibn Khaldoun, BP 78, 14000 Tiaret, Algeria

D. Robert $(\square)$

Laboratoire des Matériaux, Surfaces et Procédés pour la Catalyse, CNRS-UMR 7515, Antenne de Saint-Avold, Université de Lorraine, Rue Victor Demange,

57500 Saint-Avold, France

e-mail: didier.robert@univ-lorraine.fr consists in ejecting an electron from the valence band (VB) to the conduction band $(\mathrm{CB})$ of the semi-conductor thus creating $\mathrm{h}^{+}$hole in the valence band. This is followed by the formation of extremely reactive radicals such as $\mathrm{OH}$. at the semiconductor surface or by direct oxidation of the polluting species by $\mathrm{h}^{+}$. On the other hand, electrons are trapped at surface sites which reacted with electron acceptors such as oxygen adsorbed or dissolved in water to form superoxide radical $\mathrm{O}_{2}^{--} \cdot \mathrm{TiO}_{2}$ and especially anatase form, is considered as an excellent photocatalyst that can mineralize a large range of organic pollutants (Mills and Le Hunte 1997, Agrios and Pichat 2005, Lewandowski and Ollis 2004). This semi-conductor is the most studied material for such applications (Neppolian et al. 2002). Alternatively, $\mathrm{ZnO}$ can be considered as the second photocatalyst after $\mathrm{TiO}_{2}$, whose physical-chemical properties are comparable to those of $\mathrm{TiO}_{2}$ (Liqiang et al. 2004, Behnajady et al. 2006, Akyol and Bayramoylu 2005, Anandan et al. 2010). However, as mentioned by Liqiang et al. 2004, semiconductor photocatalysts, other than $\mathrm{TiO}_{2}$, are much less studied. Furthermore, $\mathrm{ZnO}$ nanoparticle is stable and easy to be prepared.

One of the limiting factors that control the photocatalysts' efficiency is the rapid recombination of photogenerated electron-hole pairs in semi-conductor particles. Currently, many studies are realized to limit this phenomenon. Among the proposed solutions are to be found:

- Coupling with another appropriate semi-conductor (Robert 2007, Helaili et al. 2010),

- Chemical doping with atoms such as nitrogen (Gole et al. 2004), carbon (Sakhtivel and Kisch 2003) or thallium (Kong et al. 2010),

- Addition of electron acceptors such as dissolved oxygen (Laisheng et al. 2003) 
- Or addition of soluble organic sacrificial agents such as methanol (Patsouras et al. 2007).

In a recent paper, we have proposed to incorporate a sacrificial agent insoluble in water with photocatalyst such as calcium oxalate (Bassaid et al. 2009). The role of oxalate ions is to react with photogenerated holes to limit their recombination with photogenerated electrons. In the current study, we show the effect of calcium oxalate on the photocalytique properties of $\mathrm{ZnO}$ for the removal of organic pollutants in water. Orange II is used as an organic pollutant model that will evaluate the effect of the addition of $\mathrm{Ca}(\mathrm{COO})_{2}$ on the photocatalytic performance of $\mathrm{ZnO}$.

\section{Experimental}

\section{Reagents}

All the reagents used in this work were of analytical grade and were used in their as-received state: calcium chloride (Fluka $99 \%$ ), ammonium oxalate (Merck 99\%) and Orange II (Sigma Chemical Co.). Zinc oxide (Riedel-de haen, $99.95 \%$ purity, particles size was $50 \mathrm{~nm}$ and $\mathrm{ZnO}$ phase is hexagonal structure: Wurtzite). The specific surface area of $\mathrm{ZnO}$ was determined by Brunauer, Emmett and Teller (BET) method using nitrogen gas as the adsorbent at $77 \mathrm{~K}$ on ASAP 2010 Micrometrics Apparatus. The specific area is $74.3 \mathrm{~m}^{2} \mathrm{~g}^{-1}$.

Calcium oxalate $\mathrm{Ca}(\mathrm{COO})_{2}$ was prepared by mixing aqueous solution of ammonium oxalate $(0.5 \mathrm{M})$ and calcium chloride $(0.5 \mathrm{M})$. The precipitate of calcium oxalate obtained is filtered, washed with water and dried in air at $110^{\circ} \mathrm{C}$ overnight.

\section{Adsorption experiments}

All adsorption equilibrium experiments of Orange II on the $\mathrm{ZnO}$ and $\mathrm{ZnO} / 20 \% \mathrm{Ca}(\mathrm{COO})_{2}$ sample surface were carried out in batch mode under dark conditions. Studies were made using suspensions prepared by mixing a $50-\mathrm{ml}$ solution of various initial concentrations of Orange II at their natural $\mathrm{pH}$ and $\mathrm{ZnO}$ concentration of $0.5 \mathrm{~g} \mathrm{l}^{-1}$ (in distilled water). The equilibrium concentrations of Orange II in the solutions were studied after centrifugation by measuring the change in absorption intensity at this $\lambda_{\max }$ (484 nm) using a PHILIPS Vis-spectrophotometer.

\section{Irradiation experiments}

Photocatalytic experiments were performed in a doublewalled reactor placed on the $125 \mathrm{~W}$ mercury lamp (TUNGS RAM) as a light source. The operating temperature was fixed during the experiment at $25{ }^{\circ} \mathrm{C}$ by a circulation of water. Pure $\mathrm{ZnO}$ and $\mathrm{ZnO}$ with an appropriate weight of calcium oxalate (total weight $=50 \mathrm{mg}$ ) were dispersed through stirring in a volume of $100 \mathrm{ml}$ of Orange II aqueous solution $(10 \mathrm{mg} / \mathrm{l})$ and $5 \mathrm{ml}$ of aliquot was taken out at regular time intervals. The samples were noted $\mathrm{TiO}_{2} /$ $X \% \mathrm{Ca}(\mathrm{COO})_{2}$ with " $X$ " represents the percentage of $\mathrm{Ca}(\mathrm{COO})_{2}$ in the composite. The value of the percentage corresponds to the percentage in weight of $\mathrm{Ca}(\mathrm{COO})_{2}$ in the composite. Before each irradiation, the solutions were maintained in the dark for $1 \mathrm{~h}$ to reach the adsorption equilibrium. For analysis, each sample containing catalyst was centrifuged prior and analyzed by Vis-spectrophotometer $\left(\right.$ PHILIPS) $\left(\lambda_{\max }=484 \mathrm{~nm}\right)$.

\section{Results and discussion}

Effect of calcium oxalate loading on the photocatalytic activity of $\mathrm{ZnO}$

The effect of the partial replacement of $\mathrm{ZnO}$ by calcium oxalate on the disappearance kinetics of Orange II was investigated. The percentage of calcium oxalate increases from 0 to $50 \%$ in weight for a total concentration of $\mathrm{ZnO}+$ calcium oxalate constant and equal to $500 \mathrm{mg} / \mathrm{l}$. All experiments were first carried out in dark during $60 \mathrm{~min}$, and then immediately irradiated by UV-Vis irradiation until complete decolorization of the compound. Figure 1 shows the effect of oxalate calcium on the photocatalytic decolorization of Orange II with $\mathrm{ZnO}$ under irradiation.

The photodecomposition of Orange II was subjected to photochemical degradation depending on the model of Langmuir-Hinshelwood kinetics appears to be followed satisfactorily. The photocatalytic degradation of Orange II follows a kinetic of pseudo-first order. For a low initial dye concentration, the simplest representation for the rate of photodegradation of Orange II is given by $\ln C_{t}=-k t+\ln C_{0}$.

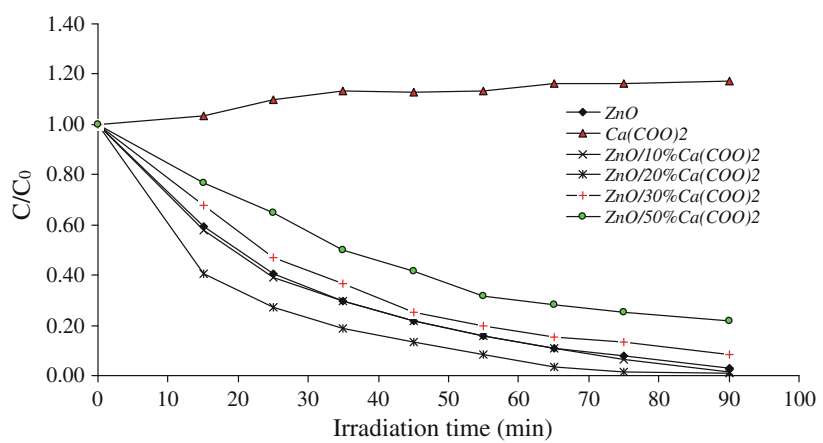

Fig. 1 Effect of calcium oxalate on the photocatalytic degradation of Orange II $([\mathrm{OII}]=10 \mathrm{mg} / \mathrm{l})$ in the presence of $\mathrm{ZnO}$ at natural $\mathrm{pH}$ 
This equation can be used to demonstrate the linearity of data. His integration is given by $\operatorname{Ln}\left(C_{0} / C_{t}\right)=k t$ where $k$ is the constant of the pseudo-first-order rate.

The obtained constant $(k)$ and half-life $\left(t_{1 / 2}\right)$ have been listed in Table 1, which reveal a significant and favorable effect of added oxalate calcium on the photocatalytic decolorization of Orange II dye with $\mathrm{ZnO}$. The $k$ and $t_{1 / 2}$ for $\mathrm{ZnO} / 20 \% \mathrm{Ca}(\mathrm{COO})_{2}$ showing the good photocatalytic activity, are equal to $5.10 \times 10^{-2} \mathrm{~min}^{-1}$ and $13.6 \mathrm{~min}$, respectively.

\section{Adsorption results}

To obtain an explanation for the effect of the oxalate on the photodegradation of Orange II by $\mathrm{ZnO}$, isotherm adsorption of pure $\mathrm{ZnO}$ and $80 \% \mathrm{ZnO} / 20 \%$ oxalate mixtures was studied. As mentioned earlier, adsorption phenomena on catalysts are of prime importance for the degradation of organic molecules.

Adsorption isotherm results of Orange II show very good adsorption onto $\mathrm{ZnO}$ and $80 \% \mathrm{ZnO} / 20 \%$ oxalate mixtures in aqueous solution compared to that of calcium oxalate alone. Langmuir adsorption model has been applied to describe the adsorption of Orange II on materials. It is given as the classical following equation:

$Q=Q_{\mathrm{ads}} / Q_{\mathrm{max}}=\frac{K_{\mathrm{ads}} C_{\mathrm{eq}}}{1+K_{\mathrm{ads}} C_{\mathrm{eq}}}$

where $Q$ is the $\mathrm{ZnO}$ surface coverage, $Q_{\text {ads }}$ the adsorbed quantity, $Q_{\max }$ the adsorption maximum capacity of Orange II on the $\mathrm{ZnO}$ surface $(\mathrm{mg} / \mathrm{g}), C_{\text {eq }}$ the concentration of Orange II at the adsorption equilibrium and $K_{\text {ads }}$ the Langmuir adsorption constant. The linear transform is given in Fig. 2. The Langmuir parameters for Orange II adsorbed on various material samples are reported in Table 2.

The results show that the maximum capacity adsorption $\left(Q_{\mathrm{m}}\right)$ of Orange II on the mixed $\mathrm{ZnO} / \mathrm{Ca}(\mathrm{COO})_{2}$ catalysts increases with oxalate weight. The value of $Q_{\mathrm{m}}$ is still higher than that of pure $\mathrm{ZnO}$ and pure oxalate in the case of the mixture $80 \% \mathrm{ZnO} / 20 \% \mathrm{Ca}(\mathrm{COO})_{2}$. This can be explained by the effect of the $\mathrm{pH}$ of medium. It is well

Table 1 First-order-rate constant $(k)$ and half life $\left(t_{1 / 2}\right)$ for the photocatalytic degradation of Orange II using $\mathrm{ZnO}$ with oxalate calcium

\begin{tabular}{llll}
\hline Catalysts & $k_{\text {app }}\left(\mathrm{min}^{-1}\right)$ & $t_{1 / 2}(\mathrm{~min})$ & $R^{2}$ \\
\hline $\mathrm{ZnO}$ & $3.50 \times 10^{-2}$ & 19.8 & 0.99 \\
$\mathrm{ZnO} / 10 \% \mathrm{Ca}(\mathrm{COO})_{2}$ & $3.80 \times 10^{-2}$ & 18.2 & 0.95 \\
$\mathrm{ZnO} / 20 \% \mathrm{Ca}(\mathrm{COO})_{2}$ & $5.10 \times 10^{-2}$ & 13.6 & 0.98 \\
$\mathrm{ZnO} / 30 \% \mathrm{Ca}(\mathrm{COO})_{2}$ & $2.80 \times 10^{-2}$ & 24.8 & 0.99 \\
$\mathrm{ZnO} / 50 \% \mathrm{Ca}(\mathrm{COO})_{2}$ & $1.80 \times 10^{-2}$ & 38.5 & 0.98 \\
\hline
\end{tabular}

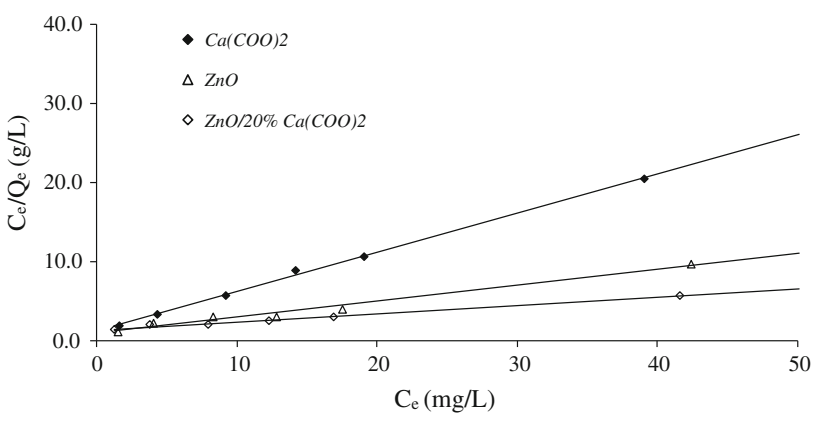

Fig. 2 Linearization of Langmuir isotherm of Orange II on $\mathrm{ZnO}$ and calcium oxalate

Table 2 Adsorption isotherm parameters of Orange II on $\mathrm{ZnO}$ and mixed $\mathrm{ZnO} /$ calcium oxalate materials

\begin{tabular}{llll}
\hline Catalysts & $\mathrm{Ca}(\mathrm{COO})_{2}$ & $\mathrm{ZnO}$ & $\mathrm{ZnO} / 20 \% \mathrm{Ca}(\mathrm{COO})_{2}$ \\
\hline$Q_{\mathrm{m}}(\mathrm{mg} / \mathrm{g})$ & 1.967 & 5.051 & 9.615 \\
$K_{\mathrm{L}}(\mathrm{L} / \mathrm{mg})$ & 0.450 & 0.200 & 0.078 \\
$R^{2}$ & 0.99 & 0.98 & 0.99 \\
\hline
\end{tabular}

known now that the adsorption of the dyes on the material semiconductors strongly depends on the $\mathrm{pH}$ of mediums (Bassaid et al. 2009; Kiriakidou et al. 1999). The natural $\mathrm{pH}$ of $\mathrm{ZnO} /$ Orange II solution is 6.8. The $\mathrm{pH}$ of zero point of charge for $\mathrm{ZnO}$ is about 9 (Sakthivel et al. 2003).

In the presence of water molecules, $\mathrm{ZnO}$ particles are covered by hydroxide groups. However, if the $\mathrm{pH}$ of the medium varies, these $\mathrm{OH}$ groups are able to give or tear off protons $\mathrm{H}^{+}$. Figure 3 shows the modification of the $\mathrm{ZnO}$ charge surface according to the $\mathrm{pH}$. In different $\mathrm{pH}$ ranges, there exist electrostatic interaction (attraction or repulsion) between the catalyst surface and the dye molecules. This phenomenon can have an effect on adsorption and consequently on photocatalytic degradation. Indeed, after added oxalate, we obtained a $\mathrm{pH}$ 6.1. This $\mathrm{pH}$ is lower than the $\mathrm{pHzpc}$, which gives to the surface of catalyst a positive load. Consequently, a strong attraction between catalyst and Orange II, since this last is dye anionic, which leads to a strong adsorption of the Orange II on the surface of catalyst.

Effect of calcium oxalate on the mechanism of Orange II photodegradation on $\mathrm{ZnO}$

In the previous work (Bassaid et al. 2009), we described the photocatalytic degradation mechanism of Orange II in the presence of the $\mathrm{TiO}_{2}$ semiconductor. In the case of $\mathrm{ZnO}$, the mechanism is similar. The first step is the photogeneration of the $\mathrm{h}^{+} / \mathrm{e}^{-}$pair by an appropriate irradiation of $\mathrm{ZnO}$. 
Fig. 3 Modification charge of surface of $\mathrm{ZnO}$ according to the $\mathrm{pH}$ in different $\mathrm{pH}$ ranges

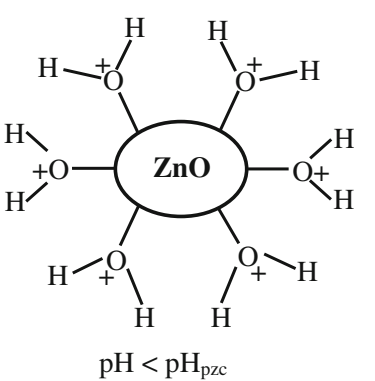

$\mathrm{pH}<\mathrm{pH}_{\mathrm{pzc}}$

$\mathrm{ZnO}+\mathrm{h} v \rightarrow \mathrm{e}_{\mathrm{CB}}^{-}+\mathrm{h}_{\mathrm{VB}}^{+}$

The holes $\mathrm{h}^{+}$react then with electron donors, such as water and $\mathrm{OH}^{-}$ions adsorbed on the surface of catalyst, to form hydroxyl radicals (like $\mathrm{OH} \cdot$ ) and/or a direct oxidation of the polluting species. The electrons, as for them, react with electron acceptors such as oxygen adsorbed, to form $\mathrm{O}_{2}^{--}$radicals. The main effect of $\mathrm{Ca}(\mathrm{COO})_{2}$ is to promote the adsorption of Orange II on the catalyst surface by lowering the $\mathrm{pH}$ of the solution.

On the other hand, calcium oxalate is oxidized by reaction with a valence band hole giving rise to a radical oxalate and to yield carbon dioxide and $\mathrm{CO}_{2}^{--}$radical (Farouzan et al. 1996).

$$
\begin{aligned}
& { }^{-}{\mathrm{OOC}-\mathrm{COO}^{-}}^{-} \mathrm{h}_{\mathrm{VB}}^{+} \rightarrow{ }^{-} \mathrm{OOC}-\mathrm{COO} \\
& { }^{-}{ }^{-} \mathrm{OOC}-\mathrm{COO} \rightarrow \mathrm{CO}_{2}+\mathrm{CO}_{2}^{--}
\end{aligned}
$$

$\mathrm{CO}_{2}^{--}$and oxalate radicals react with molecular oxygen yielding $\mathrm{O}_{2}^{--}$, where $\mathrm{O}_{2}^{--}$is in equilibrium with $\mathrm{HO}_{2}$ $(\mathrm{pKa}=4.8$ (Patsouras et al. 2007). Superoxide and hydroperoxyl radicals $\left(\mathrm{O}_{2}^{-} / \mathrm{HO}_{2}\right)$ are key intermediates because of their strong oxidizing power, which degrades Orange II compound.

These results confirm those concerning the effect of calcium oxalate with the $\mathrm{P} 25-\mathrm{TiO}_{2}$ in our previous study (Bassaid et al. 2009). The best efficiencies are obtained with 20 and $30 \%$ calcium oxalate, respectively for $\mathrm{ZnO}$ and $\mathrm{TiO}_{2}$. If we consider the ratio $k_{2} / k_{1}$ (with $k_{1}$ and $k_{2}$ : apparent rate constants for pure $\mathrm{TiO}_{2}($ or $\mathrm{ZnO})$ and $70 \%$ $\mathrm{TiO}_{2} / 30 \% \mathrm{Ca}(\mathrm{COO})_{2}$ (or $80 \% \mathrm{TiO}_{2} / 20 \% \mathrm{ZnO}$ ), respectively), we find 1.45 for $\mathrm{ZnO}$ and 1.32 for $\mathrm{TiO}_{2}-\mathrm{P} 25$.

The specific area of the two photocatalysts $\left(50 \mathrm{~m}^{2} / \mathrm{g}\right.$ for $\mathrm{TiO}_{2}$ and $67 \mathrm{~m}^{2} / \mathrm{g}$ for $\mathrm{ZnO}$ ) and the band gap values are very close $(3.2$ and $3.3 \mathrm{eV})$, which could explain these results.

\section{Conclusion}

We showed that it was possible to improve the activity of the $\mathrm{ZnO}$ photocatalyst by combining it with oxalate of calcium $\mathrm{Ca}(\mathrm{COO})_{2}$ for the photocatalytic degradation of Orange II. The results of this study show that the sacrificial

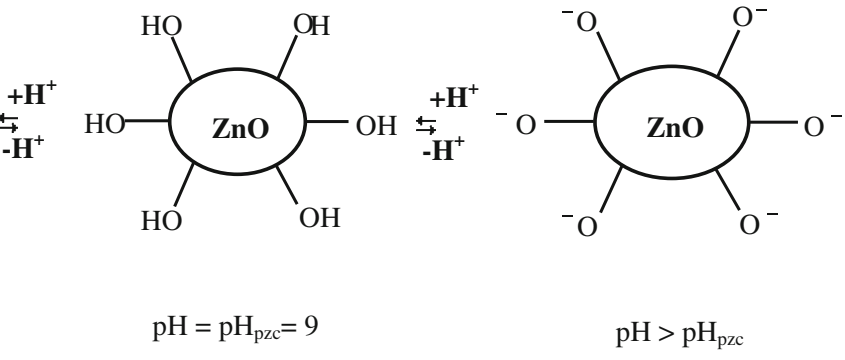

agent $\mathrm{Ca}(\mathrm{COO})_{2}$ plays a significant role in the adsorption of Orange II on the surface of the $\mathrm{ZnO}$ catalyst. In our conditions, the optimum ratio is $20 \% \mathrm{Ca}(\mathrm{COO})_{2} / 80 \%$ $\mathrm{ZnO}$. An increase in the amount of oxalate above $20 \%$ causes a decrease in the photocatalytic activity of the mixture. The calcium oxalate presence allows increasing the concentration of reactive species in the solution such as superoxides and hydroperoxides radicals.

Open Access This article is distributed under the terms of the Creative Commons Attribution License which permits any use, distribution and reproduction in any medium, provided the original author(s) and source are credited.

\section{References}

Agrios AG, Pichat P (2005) State of the art and perspectives on materials and applications of photocatalysis over TiO2. J Appl Electrochem 35:655-663

Akyol A, Bayramoylu M (2005) Photocatalytic degradation of Remazol Red F3B using ZnO catalyst. J Hazard Mater B 124: 241-246

Anandan S, Ohashi N, Miyauchi M (2010) ZnO-based visible-light photocatalyst: band-gap engineering and multi-electron reduction by co-catalyst. Appl Catal B 100:502-510

Bassaid S, Robert D, Chaib M (2009) Use of oxalate sacrificial compounds to improve the photocatalytic performance of titanium dioxide. Appl Catal B 86:93-97

Behnajady MA, Modirshahla N, Hamzavi R (2006) Kinetic study on photocatalytic degradation of C.I. Acid Yellow 23 by $\mathrm{ZnO}$ photocatalyst. J Hazard Mater 133:226-232

Farouzan F, Richards TC, Bard AJ (1996) Photoinduced reaction at TiO2 Particles. Photodeposition from NiII solutions with oxalate. J Phys Chem 100:18123-18127

Garcia JC, Simionato JI, Carli Da Silva AE, Nozaki J, Evelazio de Souza N (2009) Solar photocatalytic degradation of real textile effluents by associated titanium dioxide and hydrogen peroxide. Sol Energy 83:316-322

Gole JL, Stout JD, Burda C, Lou Y, Chen X (2004) Highly efficient formation of visible light tunable $\mathrm{TiO} 2-\mathrm{xNx}$ photocatalysts and their transformation at the nanoscale. J Phys Chem 108:12301240

Helaili N, Bessekhouad Y, Bouguelia A, Trari M (2010) p-Cu2O/n$\mathrm{ZnO}$ heterojunction applied to visible light Orange II degradation. Sol Energy 84:1187-1192

Kiriakidou F, Kondarides DI, Verykios XE (1999) The effect of operational parameters and $\mathrm{TiO} 2$-doping on the photocatalytic degradation of azo-dyes. Catal Today 54:119-130

Kong JZ, Li AD, Li XY, Zhai HF, Zhang WQ, Gong YP, Li H, Wu D (2010) Photo-degradation of methylene blue using Ta-doped ZnO nanoparticle. J Sol State Chem 183:1359-1364 
Lewandowski M, Ollis DF, Ramamurthy V, Schanke KS (eds) (2004) Semiconductor photochemistry and photophysics. Basel, New York, p 249

Laisheng L, Wanpeng Z, Zhu W, Chen Z, Han W (2003) Photocatalytic oxidation and ozonation of catechol over carbonblack-modified nano- $\mathrm{TiO}_{2}$ thin films supported on $\mathrm{Al}$ sheet. Water Res 37:3646-3651

Liqiang J, Baiqi W, Baifu X, Shudan L, Keying S, Weimin C, Honggang F (2004) Investigations on the surface modification of $\mathrm{ZnO}$ nanoparticle photocatalyst by depositing Pd. J Solid State Chem 177:4221-4227

Mills A, Le Hunte S (1997) An overview of semiconductor photocatalysis. J Photochem Photobiol A Chem 108:1-35

Neppolian B, Choi HC, Sakthivel S, Arabindoo B, Murugesan V (2002) Solar light induced and $\mathrm{TiO}_{2}$ assisted degradation of textile dye reactive blue 4 . Chemosphere 46:1173-1181

Patsouras A, Kondarides DI, Verykios XE (2007) Photocatalytic degradation of organic pollutants with simultaneous production of hydrogen. Catal Today 124:94-102
Rajeshwara K, Osugi ME, Chanmanee W, Chenthamarakshan CR, Zanoni MVB, Kajitvichyanukul P, Krishnan-Ayer R (2008) Heterogeneous photocatalytic treatment of organic dyes in air and aqueous media. J Photochem Photobiol C Photochem Rev 9:171-192

Robert D (2007) Photosensitization of $\mathrm{TiO}_{2}$ by MxOy and MxSy nanoparticles for heterogeneous photocatalysis applications. Catal Today 122:20-36

Sakhtivel S, Kisch H (2003) Daylight photocatalysis by carbonmodified titanium dioxide. Angewandte Chem Int Ed 42:49084911

Sakthivel S, Neppolian B, Shankar MV, Arabindoo B, Palanichamy M, Murugesan V (2003) Solar photocatalytic degradation of azo dye: comparison of photocatalytic efficiency of $\mathrm{ZnO}$ and $\mathrm{TiO}_{2}$ Sol. Energy Mater Sol Cells 77:65-82 